\title{
Value Chain Analysis of the Villages' Top Product on OVOP (One Village One Product) Based Village
}

\author{
Y. Hartono \\ Agriculture Faculty \\ Universitas Samawa \\ Sumbawa, Indonesia
}

\author{
A. Wartiningsih* \\ Agriculture Faculty \\ Universitas Samawa \\ Sumbawa, Indonesia \\ alwartiningsih@gmail.com
}

\author{
S. Nurwahidah \\ Agriculture Faculty \\ Universitas Samawa \\ Sumbawa, Indonesia
}

Ieke Wulan Ayu

Agriculture Faculty

Universitas Samawa

Sumbawa, Indonesia

\author{
G. Gunawan \\ Physics Education Department \\ Universitas Mataram \\ Mataram, Indonesia
}

\begin{abstract}
The chain of regional development in the context of development in rural areas is start by using a database that includes data approach one village one product (OVOP). The purpose of this research is to analyse the value chain top products based (OVOP) village. in this study have identify the value chain, by tracing the product flow from upstream to downstream, which was carried out in 2018. The results showed that fresh produce produced obtained from the cultivation and the extraction of the sea, then the process done after the harvest with simple technology. The marketing area covers Sumbawa regency to overseas, as well as processed products originating from surrounding communities that are processed in a simple process to produce products which can fulfil the needs of Sumbawa Island and several regions in Indonesia.
\end{abstract}

Keywords - Value chain analysis, one village one product

\section{INTRODUCTION}

Development is a systematic and continuous effort to create conditions that can provide various alternatives for achieving the aspirations of every citizen [1]. The main issue of national development at present is the large gap between regions so that the main policy direction of development is focused on accelerating the reduction of the gap, especially the direction of regional development which can drive transformations and acceleration. Regional development is directed to growth, equity, and the existence of a sustainable process (sustainability) [2].

The main problem in regional development lies in the emphasis on development policies based on regional uniqueness. This is related to using the potential of human resources, natural resources, financial resources and institutional resources [3]. Resolving these problems can be done by creating new jobs that support the special characteristics of the region. To create new employment opportunities and stimulate increased regional economic activity, the regional development chain in the context of rural development must begin by utilizing a database that includes data on the One Village One Product (OVOP) approach. OVOP is a community movement that integrally seeks to increase public awareness of the potential and wealth of the region, increase the income of business people and the community, and at the same time increase selfconfidence and pride in the capabilities of the community in their area [4].
Natural resources, local cultural products, and local special products that have been produced from generation to generation can be extracted and developed to produce highvalue products. Of course, it must be consistent with market demands and comes from local resources [5]. Local resources can be managed better if an area is more focused on top products. By optimizing OVOP, the community will be better in improving governance and production of regional top products. However, of course, this requires extensive and detailed data on regional top products, especially from villages in Sumbawa Island. The data can be includes form the value chains of top village products. From this background, the purpose of this study is to analyse the value chain of top village products based on OVOP (One Village One Product).

\section{RESEARCH METHOD}

The scope of the research sites were villages located in strategic area in the Sumbawa Regency, West Nusa Tenggara Province. This research was conducted from March 2018 to June 2018. The method of data collection was carried out through secondary data analysis, surveys and in-depth interviews with key informants. In addition to business people, interviews were also conducted with the marketing operators of the main products, households and / or the processing industry, tourism businesses and other key informants in each research location in each district.

Analysis of the data used is descriptive analysis with survey methods. The survey was conducted to identify the value chain, by tracing the product flow from upstream to downstream, starting from input, production, processing, collection, to marketing. Identification is carried out on priority products classified as the main results of the Analytical Hierarchy Process (AHP) conducted by Bappeda and the Sumbawa Regency Industry Office [2]. So that the economic analysis of the superior product value chains in this study is focused on several regional superior products by outlining the stages from input to product marketing [6] 


\section{RESULTS AND DISCUSSIONS}

\section{A. Regional Development Potential}

Regional development in Sumbawa Regency is directed by following topographic conditions that tend to be hilly with an altitude between 0-1,730 meters above sea level (masl); and climatology which ranges from $17.7 \mathrm{oC}-37.2 \mathrm{oC}$ area as regulated in Regional Regulation Number 10 of 2012 concerning the Sumbawa Regency Regional Spatial General Plan 2011-2031 [7]. Referring to the regional regulation, the potential for regional development is divided into two large spatial patterns, namely protected and cultivated areas. The Protected Area is directed at the preservation of space used in the context of maintaining regional space in the context of environmental sustainability/preservation, while the Cultivation Area is directed at the utilization of space in the framework of accelerating regional development sectors. Based on the Sumbawa Regency Regional Spatial Plan (RTRW) Type of Development Zone is divided into the permanent production forest area, agricultural designation area, plantation designation area, area for livestock husbandry. Seeing this, the village superior commodities based on strategic areas include 14 types of superior products/commodities consisting of seven products categorized as fresh products, and seven products categorized as processed products, consisting of (1) Fresh products consisting of corn, cattle, paddy rice, Trigona honey, coffee, candlenut, and seaweed; (2) Processed products consist of shrimp paste, fish crackers, ground coffee, candlenut oil, milk candy, coconut sugar [11]. OVOP Product / Commodity Value Chain Analysis in Sumbawa Regency

Development synergy is implemented through two approaches. First, the top-down approach, namely planned development (by design) with due regard to priorities determined nationally and followed by regional participation. Second, the bottom-up approach, namely through the determination of core competencies which are regional advantages so that they have competitiveness. Both approaches can be done by developing core competencies.

Core competence is a collection of resources and organizational capabilities that have the high uniqueness needed to achieve goals. Its uniqueness can sharpen the superiority of regional commodities. The most important thing that must be done in developing core competencies is the value chain mapping, which is a set of activities that occur for each business actor involved. The following is a value chain of four leading products/commodities in the Sumbawa Regency.

Corns

Corns are one of the promising leading commodities in the Regency of Sumbawa, where production reached 329,855 tons in 2015 . The corn commodity is a regional superior product and has been a provincial and district government program from 1999 until now. One of the corn commodity centers the Sumbawa Regency is Labangka District which is located in Labangka 1 and Labangka 2 Villages, with production reaching 48,896 tons. Corn agribusiness has very potential development prospects in Labangka District because it can become an economic foundation for farmers and related business actors. As is known corn is a superior commodity that has many benefits in industry, such as ethanol [12], hydrogen development material [13], and corn-based sugar [14]. Corn in Labangka Sub-district, in particular, has developed into a sustainable profit-oriented business venture. The following is illustrated the value chain or value chain for superior corn products in Sumbawa Regency, starting from the production process to the marketing, which is presented in Table 1.

TABLE I. VALUe Chain Process of CoRn Product (Fresh PRoduct)

\begin{tabular}{|c|c|c|c|c|}
\hline $\begin{array}{c}\text { Main } \\
\text { Process }\end{array}$ & Inbound Logistic & Operation & $\begin{array}{r}\text { Outbound } \\
\text { logistic }\end{array}$ & Marketing, sales and services \\
\hline Activities & $\begin{array}{l}\text { Planting and maintenance } \\
\text { (dry land corn } \\
\text { cultivation) }\end{array}$ & $\begin{array}{l}\text { - Land } \\
\text { preparation/management } \\
\text { - Post-harvest processing }\end{array}$ & $\begin{array}{l}\text { Delivery of corn } \\
\text { to exporters }\end{array}$ & $\begin{array}{l}\text { Marketing at the regional and } \\
\text { national levels (out of the } \\
\text { region/district) }\end{array}$ \\
\hline $\begin{array}{l}\text { Resources, capacity } \\
\text { / competency }\end{array}$ & $\begin{array}{r}- \\
\text { - Corn cultivation has } \\
\text { - Care and main } \\
\text { - Is one }\end{array}$ & $\begin{array}{l}\text { - Land and clim } \\
\text { rn commodity is cultivate } \\
\text { en cultivated since the beg } \\
\text { ance are quite intensive } \mathrm{w} \\
\text { governm } \\
\text { the regional superior prod }\end{array}$ & $\begin{array}{l}\text { Ite support } \\
\text { by the local comn } \\
\text { inning of the villag } \\
\text { th the support of te } \\
\text { ents } \\
\text { icts whose develop }\end{array}$ & $\begin{array}{l}\text { munity } \\
\text { ge opened to trans migrants } \\
\text { echnology from local } \\
\text { oment is prioritized }\end{array}$ \\
\hline
\end{tabular}

Based on Table 1 above it can be seen that the value chain of corn both from activities and availability of resources is very adequate. When viewed from the natural resources the climate is very supportive for the development of corn, support from the government is very good in developing corn commodities from seeds, fertilizers, technology to assistance so that making corn is a priority commodity. furthermore, the activities that are not interrupted from the preparation, planting to post-harvest carried out by local communities and trans migrants, until finally the corn is promoted both regionally and nationally.
Cows

For rural communities owning livestock can be of double benefit, livestock can be used as rice plowers [8] and as pets. Besides, cows have broad benefits in human life, such as dairy products [15] and fuels [16]. One of the villages which are the centre of beef cattle development in Sumbawa Regency is in Kukin Village, which is cantered in Limung Hamlet, due to the condition of the area and the potential of its land/pasture. Guaranteed certainty of the amount of sustainable supply and better quality and wide range of markets that not only meet local needs, but have penetrated to large districts in Indonesia, even some have 
been exported demanding a pattern of intensification of livestock with an agribusiness system. The development of such broad benefits from cattle has become a great opportunity for the region to be developed more broadly. Candlenut

Candlenut products and their derivatives are considered to have the potential to be developed because commodities can be expected to become commodities that can improve the regional economy [9]. When viewed from the candlenut produced, the average production can reach $500 \mathrm{~kg} / \mathrm{ha}$ up to $600 \mathrm{~kg} / \mathrm{ha} /$ year. Currently, the opportunity for exploitation/cultivation of candlenut is very open, because
Illustrate the value chain or value chains for superior products in the Regency of Sumbawa which is presented in the $2^{\text {nd }}$ Table

the local community has been able to develop hazelnut products into processed products such as hazelnut oil and its market is very promising and its management continues to be developed both in terms of cultivation and post-harvest process as well as industrial products and other derivative products from commodities candlenut. The following illustrates the value chain for the superior products of Sumbawa Regency candlenut which is presented in third table and fourth table.

TABlE II. VAlue Chain of CANDlenut Product (Fresh PRODUCT)

\begin{tabular}{clll} 
Main Process & Inbound Logistic & Operation & $\begin{array}{c}\text { Outbound } \\
\text { Process }\end{array}$ \\
\hline Activities & $\begin{array}{l}\text { Maintenance and } \\
\text { Cultivation }\end{array}$ & $\begin{array}{l}\text { Post-harvest processing (drying } \\
\text { and stripping) }\end{array}$ & $\begin{array}{l}\text { Candlenut Seed } \\
\text { Marketing at the regional and national } \\
\text { levels (out of the region / district) }\end{array}$ \\
\hline $\begin{array}{c}\text { Resources, capacity/ } \\
\text { competency }\end{array}$ & - & Land and climate support \\
\end{tabular}

TABle III. Value Chain Process of Candlenut Processed Products (Processed Product)

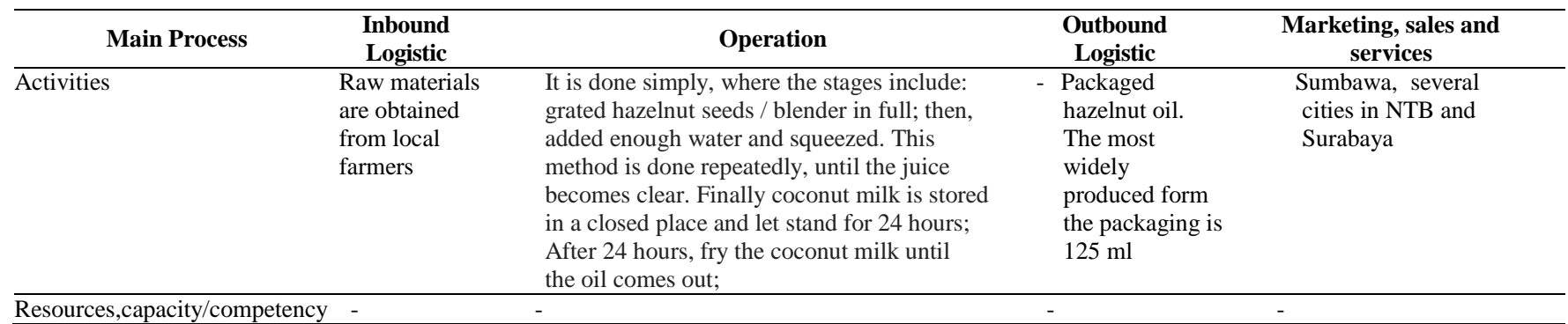

\section{Shrimp Paste and Masin Shrimp}

Tarano district, especially in Labuhan Bontong village, most of the population is involved in the shrimp processing business. This business is considered very suitable to be developed considered by the potential of marine products, especially shrimp as the main raw material for making shrimp paste reaching 5,869 tons in 2015 . With the potential for such raw materials, shrimp paste industry players can produce with a production capacity of 20 - $50 \mathrm{~kg} / \mathrm{day}$. The general problems faced by shrimp paste and masin shrimp producers in Labuhan Bontong Village, namely: a). Availability of raw materials. Shrimp paste production is very dependent on the catches of fishermen in the Labuhan Bontong and surrounding areas because the raw material of this shrimp paste is fresh shrimp. After all, it will affect the taste of the saltiness or Shrimp paste itself. b) Processing technology.

TABle IV. VAlue Chain Process of CoRn Product (FRESH PRODUCT)

\begin{tabular}{cccc}
\hline Mainly Process & \multicolumn{1}{c}{ Inbound Logistic } & Operation & Outbound Logistics \\
\hline Activities & maintenance and cultivation & $\begin{array}{l}\text { Shipping the cattle to the } \\
\text { exporter }\end{array}$ & $\begin{array}{l}\text { Marketing at the regional and } \\
\text { national levels (out of the } \\
\text { region/district) }\end{array}$ \\
\hline $\begin{array}{c}\text { Resources, } \\
\text { capacity/competency }\end{array}$ & - & - Land and climate support \\
& - & - Cow cultivation is cultivated by the local community \\
& & - Care and maintenance that is quite unique, namely the system is free / LAR \\
& with support from local governments \\
& - Is a regional superior product prioritized for its development \\
\hline
\end{tabular}

Management of the production process is still carried out traditionally as did their predecessors. So it is incapable of the use of fuel and ineffective in production. c) Marketing. Marketing still revolves around the areas of Tarano, Empang, and the Sumbawa region. The packaging is still very simple or very traditional. The value chain or value chain for shrimp paste products in Labuhan Bontong Village starts from the production process to its marketing which is presented in $5^{\text {th }}$ table. 
TABLE V. $\quad$ (PROCESSED PRODUCT)

\begin{tabular}{|c|c|c|c|c|}
\hline Main Process & Inbound Logistic & Operation & Outbound Logistic & $\begin{array}{c}\text { Marketing, sales and } \\
\text { services }\end{array}$ \\
\hline Activities & $\begin{array}{l}\text { Catching marine } \\
\text { product (Shrimp) }\end{array}$ & $\begin{array}{l}\text { Ebi / small shrimp are cleaned, } \\
\text { boiled, pounded with simple } \\
\text { tools (like mortar) with } \\
\text { additional seasonings (salt and } \\
\text { chili), then stored. The product } \\
\text { can last for } 3 \text { months }\end{array}$ & $\begin{array}{l}\text { Shrimp paste is produced } \\
\text { with average of } 20-50 \mathrm{~kg} \\
\text { per day }\end{array}$ & $\begin{array}{l}\text { Marketing around } \\
\text { Terano and Empang } \\
\text { districts and several } \\
\text { shops in Sumbawa }\end{array}$ \\
\hline Resources, & $\begin{array}{l}\text { Capability / competen } \\
{[10]}\end{array}$ & ture by local fishermen with sin & ple fishing gear with an ave & yield of 450 Tons / Year \\
\hline
\end{tabular}

\section{CONCLUSION}

Based on the results of this research it can be concluded that the leading commodity value chain of Sumbawa Regency consists of fresh and processed products. Fresh produce produced is obtained from aquaculture activities or extraction from the sea, which is then carried out postharvest processing with simple technology. The marketing area covers Sumbawa Regency to Overseas. Likewise the products processed by utilizing products. The Product produced by the surrounding community, processed with a simple process so as to produce products that can meet the needs of Sumbawa Island and several regions in Indonesia.

\section{ACKNOWLEDGMENT}

Gratefully thanks to:

1. Lembaga Penelitian dan Pengabdian Kepada Masyarakat (LPPM) which has supported this research activities.

2. Badan Perencanaan Pembangunan Daerah (BAPPEDA) which has funded this research activity.

3. Villagers in the research location who have provided information and supported this research.

\section{REFERENCES}

[1] Ayu I W, 2017. Critical Review: Penentuan Pusat-Pusat Pertumbuhan Dalam Pengembangan Wilayah Di Kabupaten Gunung Kidul. Jurnal Ilmu Pertanian. Volume 2 No 2 Juni 2017, Hal 39-54

[2] Nurwahidah S, IRE Yogyakarta, 2019. Pengembangan Ekonomi Lokal (BUMDES) dengan Pendekatan Sustainability Livelihooh (PSL) di Desa Sabedo Kacamatan Utan Kabupaten Sumbawa. Jurnal Ilmu Pertanian. Volume 1 No 1 Januari 2019, Hal 59-72

[3] Wartiningsih A, Hakim L, 2018. Analisis Sosial Ekonomi Usaha Black Honey Pada Kawasan Sentra Pembudidayaan Trigona Sp. Jurnal Ilmu Pertanian. Vol 1. No 1. Januari 2018, hal 16-29

[4] Hakim L, 2018. Kajian Analisis One Village One Product (OVOP) Kabupaten Sumbawa. Jurnal Riset Kajian Teknologi dan Lingkungan. Vol 1 No 1 Mei 2018, hal 1-9

[5] Hartono Y, Sudirman, 2017. Analisis Nilai Tambah Produk Olahan Rumput Laut. Jurnal Ilmu Pertanian. Volume 11 No 1 Januari 2017, Hal 109-117

[6] Julianto E W, Darwanto, 2016. Analisis Rantai Nilai (Value Chain) Jagung di Kecamatan Toroh Kabupaten Grobogan. Jurnal Penelitian Ekonomi dan Bisnis. Volume 1 No 1 Maret 2016, hal $1-15$

17] Badan Perencanaan Pembangunan Daerah [Bappeda]. 2016. Rencana Pembangunan Jangka Menengah Daerah (RPJMD) Kabupaten Sumbawa 2016-2021. Bappeda Kabupaten Sumbawa. SumbawaBesar.

[8] Hamdani A, Liliani, 2017. Analisis Pemasaran Ternak Sapi Di Wilayah Sentra Peternakan Rakyat (SPR) Di Kecamatan Moyo
Utara Kabupaten Sumbawa. Jurnal Ilmu Pertanian. Volume 2 No 2 Juni 2017, Hal 14-26

[9] Hartono Y, Irwansyah, 2018. Analisis Nilai Manfaat Ekonomi Hasil Hutan Bukan Kayu (HHBK) di Desa Batudulang Kecamatan Batulanteh Kabupaten Sumbawa. Jurnal Ilmu Pertanian. Volume 1 No 1 Januari 2018, Hal 107

[10] Badan Pusat Statistik. 2016. Kabupaten Sumbawa Dalam Angka 2016. BPS Kabupaten Sumbawa. Sumbawa

[11] Badan Perencanaan Pembangunan Daerah [Bappeda]. 2016. Produk Unggulan Daerah Kabupaten Sumbawa. Bappeda Kabupaten Sumbawa. Sumbawa Besar.

[12] Wang, M., Han, J., Dunn, J. B., Cai, H., \& Elgowainy, A. (2012). Well-to-wheels energy use and greenhouse gas emissions of ethanol from corn, sugarcane and cellulosic biomass for US use. Environmental research letters, 7(4), 045905.

[13] Zhang, Y., Hu, G., \& Brown, R. C. (2013). Life cycle assessment of the production of hydrogen and transportation fuels from corn stover via fast pyrolysis. Environmental Research Letters, 8(2), 025001 .

[14] Iop, S. C. F., Silva, R. S. F., \& Beleia, A. P. (1999). Formulation and evaluation of dry dessert mix containing sweetener combinations using mixture response methodology. Food chemistry, 66(2), 167-171.

[15] Downey, L., \& Doyle, P. T. (2007). Cow nutrition and dairy product Manufacture-Implications of seasonal pasture-based milk production systems. Australian Journal of Dairy Technology, 62(1), 3.

[16] Pooja, S., Pushpanathan, M., Jayashree, S., Gunasekaran, P., \& Rajendhran, J. (2015). Identification of periplasmic $\alpha$-amlyase from cow dung metagenome by product induced gene expression profiling (pigex). Indian journal of microbiology, 55(1), 57-65. 